\title{
DETERMINAN OPINI AUDIT GOING CONCERN PERUSAHAAN MANUFAKTUR DI INDONESIA
}

\author{
Indira Shinta Dewi, SE., MM., Ak \\ indiradewi20@gmail.com
}

\section{Fakultas Ekonomi dan Bisnis - Program Studi Akuntansi Universitas Satya Negara Indonesia}

\begin{abstract}
ABSTRAK
Penelitian ini bertujuan untuk mengetahui secara parsial mengenai determinan pemberian opini audit going concern yang diproksikan dengan likuiditas, leverage, kondisi keuangan terhadap opini audit going concern pada perusahaan manufaktur di Indonesia yang terdaftar di Bursa Efek Indonesia.

Populasi penelitian ini adalah perusahaan manufaktur yang terdaftar di Bursa Efek Indonesia periode 2017 - 2019. Teknik sampel menggunakan puporsive sampling sample yang digunakan sebanyak 145. Data yang digunakan adalah data sekunder yang dilakukan dengan cara pengumpulan data teknik documenter, internet research dan diolah dengan menggunakan aplikasi SPSS versi 22.

Hasil penelitian ini menunjukan secara parsial variabel likuiditas dan kondisi keuangan, tidak berpengaruh terhadap opini audit going concern. Sedangkan variabel leverage berpengaruh terhadap opini audit audit going concern.

Kata Kunci : likuiditas, leverage, kondisi keuangan, opini audit going concern.
\end{abstract}

\section{ABSTRACT}

This study aims to determine partially about determinate going concern audit opinion in proxy of liquidity, leverage, financial condition, previous year's audit opinion on going concern audit opinion on manufacturing companies listed on the Indonesia Stock Exchange.

The population in this study is manufacturing companies listed on the Indonesia Stock Exchange for the period 2017 - 2019. The sample technique uses puporsive sampling so that the sample used are 145. The data used are secondary data which is done by collecting documentary data techniques, internet research and processed using the SPSS version 22 application.

The results of this study indicate partially liquidity and financial condition, are not significant to the provision of going concern audit opinion. Whereas the leverage positive and significant effect on the provision of going concern audit opinion.

Keywords: liquidity, leverage, financial condition, going concern audit opinion.

Jurnal Ilmiah Akuntansi dan Ekonomi Volume. 6 Nomor. 1, Februari 2021 Hal. 35 


\section{PENDAHULUAN}

\section{Latar Belakang}

Teori agensi menjelaskan potensi konflik kepentingan diantara berbagai pihak dalam perusahaan. Sebagai agent, manajer bertanggung jawab secara moral untuk mengoptimalkan keuntungan para principal, namun demikian manajer juga menginginkan untuk selalu memperoleh kompensasi sesuai dengan kontrak. Konflik kepentingan ini terjadi dikarenakan perbedaan tujuan dari masing-masing pihak berdasarkan posisi dan kepentingannya terhadap perusahaan.

Herry, dan Aquariza dalam Sussanto, (2012) mengungkapkan bahwa auditor merupakan pihak yang dianggap mampu dalam menjembatani hubungan antara principal dan agent dalam mengelola suatu keuangan perusahaan. Auditor dapat memberikan opini mengenai kewajaran atas laporan keuangan perusahaan juga mempertimbangkan akan kelangsungan hidup perusahaan.

Kewajaran suatu laporan keuangan dapat dipengaruhi oleh kelangsungan usaha perusahaan sehingga going concern merupakan bagian dari pertimbangna auditor untuk memberikan opini. Auditor dapat mengeluarkan Opini audit going concern untuk memberikan kepastian kepada public mengenai kelangsungan hidup perusahaan (Ikatan Akuntan Indonesia, 2007).

Determinan opini audit going concern dapat dipengaruhi oleh faktor likuiditas, leverage dan kondisi keungan. Salah satu factor yang mempengaruhi opini going concern adalah likuiditas. Likuiditas mengukur kemampuan perusahaan untuk membayar semua kewajiban finansial jangka pendek pada saat jatuh tempo dengan menggunakan aktiva lancar yang tersedia (Syamsuddin 2001: 41). Tingkat likuiditas merupakan rasio yang mengukur kemampuan perusahaan dalam memenuhi kewajiban jangka pendeknya kepada kreditor jangka pendek (Hanafi, Mamduh dan Abdul Halim, 2009).

Mengukur leverage perusahaan dapat mempengaruhi opini seorang auditor, ratio leverage digunakan untuk mengetahui kapasitas perusahaan dalam memenuhi kewajibannya baik itu jangka pendek maupun jangka panjang. Auditor dapat mendeteksi sehat tidaknya perusahaan dari kemampuannya untuk membayar kewajiban jangka pendeknya. Kemampuan dalam mendeteksi tersebut dapat membantu auditor dalam memberikan opininyaRasio leverage yang semakin tinggi memberikan petunjuk kinerja keuangan perusahaan yang semakin buruk dan dapat menimbulkan ketidakpastian mengenai kelangsungan hidup perusahaan. Perusahaan yang memiliki aktiva yang lebih kecil dari pada kewajibannya akan menghadapi bahaya kebangkrutan (Chen dan Church,1992).

Kondisi keuangan perusahaan merupakan suatu cerminan atas keadaan keuangan suatu perusahaan dalam kurun waktu atau periode tertentu (Siahaan, 2010) dalam Dewayanto (2011), Perusahaan akan menerima audit going concern jika kondisi keuangan suatu perusahaan semakin memburuk, Sebaliknya, perusahaan yang tidak

Jurnal Ilmiah Akuntansi dan Ekonomi Volume. 6 Nomor. 1, Februari 2021 Hal. 36 
mengalami gangguan dalam kondisi keuangannya, maka kemungkinan kecil auditor memberikan opini audit going concern.

Beberapa peneliti terdahulu telah melakukan beberapa penelitian terkait topik tersebut. Menurut Widyantari (2011) bahwa likuiditas tidak berpengaruh pada opini audit going concern. Beberapa penelitian seperti Ayu (2011), Indira (2008), Mutcher et al. (1997), Totok (2011), Chen (1996) dan Herry et al.,(2012) menunjukkan bahwa faktor - faktor seperti rasio keuangan likuiditas, leverage, dan kondisi keuangan mempunyai pengaruh terhadap penerbitan opini audit going concern.

Penelitian mengenai ratio keuangan terhadap opini going concern sudah banyak dilakukan namun semuanya mempunyai hasil yang berbeda, sehingga penelitian masih menarik untuk diteliti dengan judul "DETERMINAN OPINI AUDIT GOING CONCERN PERUSAHAAN MANUFAKTUR DI INDONESIA."

\section{Perumusan Masalah}

Berdasarkan latar belakang diatas, maka dapat dirumuskan permasalahan sebagai berikut :

1. Apakah likuiditas berpengaruh terhadap pemberian opini audit going concern?

2. Apakah leverage berpengaruh terhadap pemberian opini audit going concern?

3. Apakah kondisi keuangan berpengaruh terhadap pemberian opini audit going concern?

\section{Tujuan penelitian}

Berdasarkan rumusan masalah diatas, tujuan dari penelitian ini adalah :

1. Mendapatkan bukti empiris mengenai pengaruh likuiditas terhadap pemberian opini audit going concern.

2. Mendapatkan bukti empiris empiris mengenai pengaruh leverage terhadap pemberian opini audit going concern.

3. Mendapatkan bukti empiris mengenai pengaruh kondisi keuangan terhadap pemberian opini audit going concern.

\section{Manfaat Penelitian}

Penelitian ini diharapkan dapat memberikan manfaat kepada :

1. Pengembangan teori

Penelitian ini berkontribusi pada pengambangan teori agency yang berhubungan dengan opini audit going concern

2. Kegunaan Praktis

a. Bagi peneliti / pembaca

Dapat menambah wawasan peneliti mengenai determinan opini audit going concern

b. Bagi perusahaan

Dapat memberikan kontribusi bagi pihak manajemen mengenai hal apa saja yang dapat menyebabkan auditor memberikan opini audit going concern

Jurnal Ilmiah Akuntansi dan Ekonomi Volume. 6 Nomor. 1, Februari 2021 Hal. 37 


\section{LANDASAN TEORI}

\section{Teori Agensi (Agency Theory)}

Teori agensi mampu menjelaskan potensi konflik kepetingan diantara berbagai pihak yang berkepentingan dalam perusahaan tersebut. Konflik kepentingan ini terjadi dikarenakan perbedaan tujuan dari masing-masing pihak berdasarkan posisi dan kepentingannya terhadap perusahaan. Sebagai agent, manajer bertanggung jawab secara moral untuk mengoptimalkan keuntungan para principal, namun demikian manajer juga menginginkan untuk selalu memperoleh kompensasi sesuai dengan kontrak. Dengan demikian terdapat dua kepentingan yang berbeda didalam perusahaan dimana masing-masing pihak berusaha untuk mencapai atau mempertahankan tingkat kemakmuran yang dikehendaki (Waryanto, 2010).

Teori keagenan dalam penelitian ini dikaitkan berdasarkan International Standard on Auditing (ISA) yang berlaku di Indonesia sejak 2013. ISA 570 (2009) stated that International Standard on Auditing (ISA) deals with the auditor's responsibilities in the audit of financial statements relating to management's use of the going concern assumption in the preparation of the financial statements.

\section{Pengertian Audit}

Audit menurut Agoes Sukrisno (2012) adalah suatu pemeriksaan yang dilakukan secara kritis dan sistematis, oleh pihak yang independen, terhadap laporan keuangan yang telah disusun oleh manajemen, beserta catatan-catatan pembukuan dan seluruh bukti pendukung, bertujuan memberikan pendapat mengenai laporan keuangan yang wajar.

Mulyadi (2009: 9) mengatakan bahwa audit adalah suatu proses sistematis untuk memperoleh dan mengevaluasi bukti secara objektif mengenai penyataan-pernyataan tentang kegiatan dan kejadian ekonomi, dengan tujuan untuk menetapkan tingkat kesesuaian antara pernyataan-pernyataan tersebut dengan kriteria yang telah ditetapkan.

\section{Standar Audit}

IAPI, 2011: 150.1 menyatakan bahwa laporan auditor harus memuat pernyataan pendapat mengenai laporan keuangan secara keseluruhan atau suatu asersi. Memberikan alasan yang jelas jika pendapat tidak dapat diberikan secara keseluruhan.

\section{Opini Audit}

Pernyataan Standar Auditing Nomor 29 seksi 508 Standar Profesional Akuntansi Publik (2011) menjelaskan bahwa tujuan audit atas laporan keuangan oleh auditor independen adalah untuk menyatakan pendapat tentang kewajaran mengenai posisi keuangan, hasil usaha, semua hal yang material dan perubahan arus kas, ekuitas, dan sesuai dengan akuntansi yang berlaku umum di Indonesia.

Laporan auditor dapat dijadikan sarana oleh auditor untuk memberikan opininya/pendapatnya, atau apabila keadaan mengharuskan, untuk menyatakan tidak memberikan opini/pendapat (SPAP, SA Seksi 110, Paragraf 1). Auditor menyatakan pendapat atau tidak memberikan pendapat harus menyatakan apakah auditnya telah

Jurnal Ilmiah Akuntansi dan Ekonomi Volume. 6 Nomor. 1, Februari 2021 Hal. 38 
dilaksanakan berdasarkan standar auditing yang ditetapkan Institut Akuntan Publik Indonesia. Auditor mengumpulkan bukti-bukti kewajaran informasi dengan cara memeriksa catatan akuntansi yang mendukung laporan tersebut (Astuti, 2012).

Menurut Standar Profesional Akuntan Publik per 31 Maret 2011 (PSA 29 SA Seksi 508), ada lima jenis pendapat akuntan, yaitu:

\section{Pendapat Wajar Tanpa Pengecualian (Unqualified Opinion)}

Jika auditor telah melaksanakan pemeriksaan sesuai dengan standar auditing yang ditentukan oleh Ikatan Akuntan Indonesia (IAI), seperti yang terdapat dalam standar profesional akuntan publik, dan telah mengumpulkan bahan bahan pembuktian (audit evidence) yang cukup untuk mendukung opininya, serta tidak menemukan adanya kesalahan material atas penyimpangan dari SAK/ETAP/IFRS, maka auditor dapat memberikan pendapat wajar tanpa pengecualian.

Bahwa laporan keuangan yang disajikan secara wajar, dalam semua hal yang material, posisi keuangan, hasil usaha, perubahan ekuitas, dan arus kas suatu entitas sesuai dengan SAK/ETAP/IFRS seorang auditor memberikan pendapat wajar tanpa pengecualian.

2. Pendapat Wajar Tanpa Pengecualian Dengan Bahas Penjelasan Yang Ditambahkan Dalam Laporan Audit Bentuk Baku (Unqualified Opinion With Explanatory Language).Pendapat ini diberikan jika terdapat kendaraan tertentu yang mengharuskan auditor menambahkan paragraf penjelasan (atau bahasa penjelasan lain) dalam laporan audit, meskipun tidak mempengaruhi pendapat wajar tanpa pengecualian yang dinyatakan oleh auditor. Keadaan tersebut meliputi:

a. Pendapat wajar sebagaian didasarkan atas laporan auditor independent lain.

b. Untuk mencegah agar laporan keuangan tidak menyesatakan karena keadaan keadaan yang luar biasa, laporan keuangan disajikan menyimpang dari suatu standar akuntansi yang dikeluarkan oleh Ikatan Akuntan Indonesia (IAI).

c. Jika auditor semula yakin tentang adanya kesangsian mengenai kelangsungan hidup entitas namun setelah mempertimbangkan rencana manajemen auditor berkesimpulan bahwa rencana manajemen tersebut dapat secara efektif dilaksanakan dan pengungkapan mengenai hal itu telah mamadai.

d. Diantara dua periode akuntansi terdapat suatu perubahan material dalam penggunaan standar akuntansi atau dalam metode penerapannya.

e. Keadaan tertentu mengenai laporan audit atas laporan keuangan komparatif.

f. Data keuangan kuartalan tertentu yang diharuskan oleh Otoritas Jasa Keuangan (OJK) namun tidak disajikan atau tidak direview.

g. Informasi tambahan diharusakan oleh Ikatan Akuntan Indonesia Dewan Standar Akuntansi Keuangan telah dihilangkan, yang penyajiannya menyimpang jauh dari pedoman yang dikeluarkan oleh Dewan tersebut, atau auditor tidak dapat menghilangkan keraguan besar apakah informasi tambahan tersebut sesuai dengan panduan yang dikeluarkan oleh dewan tersebut.

h. Laporan keuangan yang diaudit secara material tidak konsisten dengan informasi yang disajikan dalam laporan keuangan.

3. Pendapat Wajar Dengan Pengecualian (Qualified Opinion)

Jurnal Ilmiah Akuntansi dan Ekonomi Volume. 6 Nomor. 1, Februari 2021 Hal. 39 
Kondisi tertentu mungkin memerlukan pendapat wajar dengan pengecualian. Pendapat wajar dengan pengecualian menyatakan bahwa laporan keuangan menyajikan secara wajar, dalam semua hal yang material, posisi keuangan, hasil usaha, perubahan ekuitas, dan arus kas sesuai dengan SAK/ETAB/IFRS, kecuali untuk dampak hal yang berkaitan dengan yang dikecualikan. Pendapat ini dinyatakan bilamana:

a.Ketiadaan bukti kompeten yang cukup atau adanya pembatasan terhadap lingkup audit yang mengkibatkan auditor berkesimpulan tidak menyatakan pendapat.

b. Auditor yakin, atas dasar auditnya, bahwa laporan keuangan berisi penyimpangan dari SAK/ETAP/IFRS, yang berdampak material dan ia berkesimpulan untuk tidak menyakatan pendapat tidak wajar.

c. Jika auditor menyatakan pendapat wajar dengan pengecualian, ia harus menjelaskan semua alasan yang dicantumkan sebelum paragraf pendapat. Ia harus juga mencantumkan bahasa pengecualian yang sesuai dan menunjuk ke paragraf penjelasnya di dalam paragraf pendapat itu.

4. Pendapat Tidak Wajar (Adverse Opinion)

Prenyataan auditor yang ditetapkan jika laporan keuangan tidak menyajikan secara wajar mengenai hasil usaha, posisi keuangan, perubahan ekuitas, dan arus kas sesuai dengan SAK/ETAP/IFRS.

Apakah auditor menyatakan pendapat tidak wajar, ia harus menjelaskan dalam paragraf terpisah sebelum paragraf pendapat dalam laporannya. Semua alasan yang mendukung pendapat tidak wajar dan dampak utama hal yang menyebabkan pemberian pendapat tidak wajar terhadap posisi keuangan, hasil usaha, perubahan ekuitas dan arus kas, jika secara praktis untuk dilaksanakan. Jika dampak tersebut tidak dapat ditentukan secara beralasan, laporan audit harus menyatakan hal itu.

5. Pernyataan Tidak Memberikan Pendapat (Disclaimer opinion)

Suatu pernyataan tidak memberikan pendapat menyakatan bahwa auditor tidak menyatakan pendapat atas laporan keuangan. Auditor dapat tidak menyatakan suatu pendapat bilamana ia tidak dapat merumuskan atau tidak merumuskan suatu pendapat tentang kewajaran laporan keuangan sesui dengan SAK/ETAP/ IFRS. Jika auditor tidak menyatakan memberikan pendapat, laporan, laporan auditor harus memberikan semua alasan substantif yang mendukung pernyataan tersebut.

\section{Kinerja Keuangan}

Prastowo dalam Putri Hidayatul Fajrin (2016) unsur dari kinerja keuangan perusahaan merupakan secara langsung unsur yang berkaitan dengan pengukuran kinerja perusahaan yang disajikan di laporan laba rugi. Pengukuran kinerja (performing measurement), yaitu efisiensi dan kualifikasi serta efektifitas perusahaan selama pengoperasian bisnis dalam periode akuntansi. Dengan demikian pengertian kinerja adalah suatu usaha formal yang dilaksanakan perusahaan untuk mengevaluasi efisien dan efektivitas dari aktivitas perusahaan yang telah dilaksanakan pada periode waktu tertentu Hanafi (2009:69).

Jurnal Ilmiah Akuntansi dan Ekonomi Volume. 6 Nomor. 1, Februari 2021 Hal. 40 


\section{Rasio Likuiditas}

Menurut Van Horne dan Wachowicz (2012:205), likuiditas merupakan rasio mengukur seberapa besar kemampuan perusahaan untuk memenuhi kewajiban jangka pendeknya. Di rasio ini kewajiban jangka pendek dibandingkan dengan sumber daya jangka pendek (aktiva lancar) yang tersedia untuk memenuhi kewajiban jangka pendek tersebut".

\section{Current Ratio (CR)}

Sebagai parameter dari rasio likuiditas, penulis menggunakan Current Ratio (CR). Current ratio membandingkan aktiva lancar dengan kewajiban lancar, merupakan ukuran yang paling umum digunakan untuk melihat kemampuan perusahaan untuk memenuhi kewajiban jangka pendeknya atau dengan kata lain current ratio merupakan merupakan rasio untuk mengukur kemampuan perusahaan dalam membayar kewajiban jangka pendeknya atau utang yang segera jatuh tempo pada saat dirtagih. Rasio Lancar dapat mengukur seluruh total kekayaan perusahaan dan jumlah uang liquid yang tersedia dalam perusahaan baik untuk operasional maupun untuk membayar hutang jangka pendeknya.

\section{Rasio Leverage}

Menurut Van Horne dan Wachoviz (2012:233) Rasio solvabilitas atau leverage adalah mengukur perbandingan dana yang disediakan oleh pemiliknya dengan dana yang dipinjam dari kreditur perusahaan tersebut.

Menurut Sudana (2015: 180) leverage timbul karena perusahaan dalam operasinya menggunakan aktiva dan sumber dana yang menimbulkan beban tetap bagi perusahaan.

\section{Debt to Equity Ratio (DER)}

Indikator yang digunakan adalah Debt to Equity Ratio (DER) yaitu hasil perbandingan antara total hutang perusahaan dengan total ekuitas yang dimilikinya. Debt to equity ratio (DER) merupakan jenis rasio leverage yang digunakan untuk untuk menilai besarnya modal perusahaan yang dibiayai oleh utang.

\section{Kondisi Keuangan}

Fanny dan Saputra (2005) menemukan bahwa penggunaan model prediksi kebangkrutan yang dikembangkan oleh Altman mempengaruhi ketepatan pemberian opini audit. Penelitian yang dilakukan oleh Setyarno, dkk, (2006) juga berhasil membuktikan bahwa model prediksi kebangkrutan Altman berpengaruh terhadap penerimaan opini audit going concern. Hal ini menunjukkan bahwa perusahaan yang terancam bangkrut berpeluang mendapatkan opini audit going concern dari auditor.

Sampai dengan saat ini, Z-score model ini masih lebih banyak digunakan oleh para peneliti, praktisi serta para akademis di bidang akuntansi dibandingkan dengan model prediksi kebangkrutan lainnnya (Altman, 1993) dalam Fanny dan Saputra, 2005. Hasil penelitian yang dikembangkan Altman:

$$
Z=0,717 Z_{1}+0,874 Z_{2}+3,107 Z_{3}+0,420 Z_{4}+0,998 Z_{5}
$$

Jurnal Ilmiah Akuntansi dan Ekonomi Volume. 6 Nomor. 1, Februari 2021 Hal. 41 


$$
\begin{aligned}
& \text { Dimana: } \\
& \mathrm{Z}_{1}=\text { working capital / total assets } \\
& \mathrm{Z}_{2}=\text { retained earnings / total assets } \\
& \mathrm{Z}_{3}=\text { earnings before interest and taxes / total assets } \\
& \mathrm{Z}_{4}=\text { book value of equity / book value of debt } \\
& \mathrm{Z}_{5}=\text { sales / total assets }
\end{aligned}
$$

\section{Kerangka Berfikir}

Teori agency melandasi penelitian ini, teori agensi menjelaskan adanya konflik kepentingan yang terjadi diperusahaan dikarenakan perbedaan tujuan dari masingmasing pihak berdasarkan posisi dan kepentingannya terhadap perusahaan.

Pihak principal (pemegang saham) dan agen (manajer) memiliki sebuah hubungan timbal balik, dimana principal sebagai pihak yang memberikan wewenang dan mengevaluasi kinerja dari agen, dan agen sebagai pihak yang mengelola perusahaan dan mengambil keputusan atas nama pemegang saham. Dalam pengambilan keputusan dibutuhkan pihak independent dalam hal ini auditor untuk melakukan pemeriksaan terhadap laporan keuangan yang telah disusun oleh manajemen, beserta catatan - catatan pembukuan dan bukti - bukti pendukungnya dengan tujuan untuk dapat memberikan pendapat mengenai kewajaran suatu laporan keuangan sehingga auditor dianggap mampu menjadi penengah di konflik tersebut.Tujuan dilakukannya pemeriksaan oleh auditor independen adalah untuk menyatakan pendapat tentang kewajaran mengenai semua hal yang material, posisi keuangan, hasil usaha, perubahan ekuitas, dan arus kas sesuai dengan akuntansi yang berlaku umum di Indonesia.

Saat melakukan audit, auditor harus mengumpulkan bukti - bukti tentang kewajaran informasi yang tercantum dalam perusahaan, dengan cara memeriksa catatan - catatan akuntansi yang mendukung laporan tersebut, pernyataan pendapat auditor harus didasarkan atas audit yang telah dilaksanakan berdasarkan auditing dan temuan - temuannya. Dalam temuan tersebut auditor akan menilai kemampuan perusahaan dalam keberlangsungan hidup perusahaan. Auditor dapat memberikan pendapat going concern jika dianggap perusahaan mempunyai masalah keuangannya.

Saat melakukan pemeriksaan terhadap laporan keuangan seorang auditor harus mempertimbangkan faktor keuangan perusahaan. Pada penelitian ini determinan pemberian opini audit going concern dapat dilihat dari faktor keuangan yang digunakan yaitu likuiditas yang diproksikan dengan current ratio dengan cara membandingkan antara total aktiva lancar dengan total utang lancar. Faktor keuangan selanjutnya adalah rasio leverage yang diproksikan dengan debt to equity ratio untuk mengetahui jumlah dana yang disediakan peminjam (kreditor) dengan pemilik perusahaan. Kondisi keuangan perusahaan yang diproksikan dengan aldman Z-score digunakan untuk melihat kemungkinan perusahaan untuk gagal atau bangkrut sebagai ukuran dari keseluruhan kinerja perusahaan. Ketiga variable yaitu likuiditas, leverage dan kondisi keuangan tersebut akan diuji bagaimana pengaruhnya terhadap opini audit going concern.

Jurnal Ilmiah Akuntansi dan Ekonomi Volume. 6 Nomor. 1, Februari 2021 Hal. 42 


\section{METODOLOGI PENELITIAN}

\section{Design Penelitian}

Design penelitian bersifat kausal atau uji hipotesis dengan tujuan untuk menguji determinan pemberian opini audit going concern berupa factor keuangan perusahaan ( likuiditas, leverage dan kondisi keuangan). Lingkup penelitian berupa penelitian statistic untuk menguji hipotesis yang dilakukan. Lingkup penelitian meliputi studi pustaka dengan tujuan untuk memperoleh landasan teori yang mendukung topic penelitian.

\section{Gambar 1: Desain Penelitian}

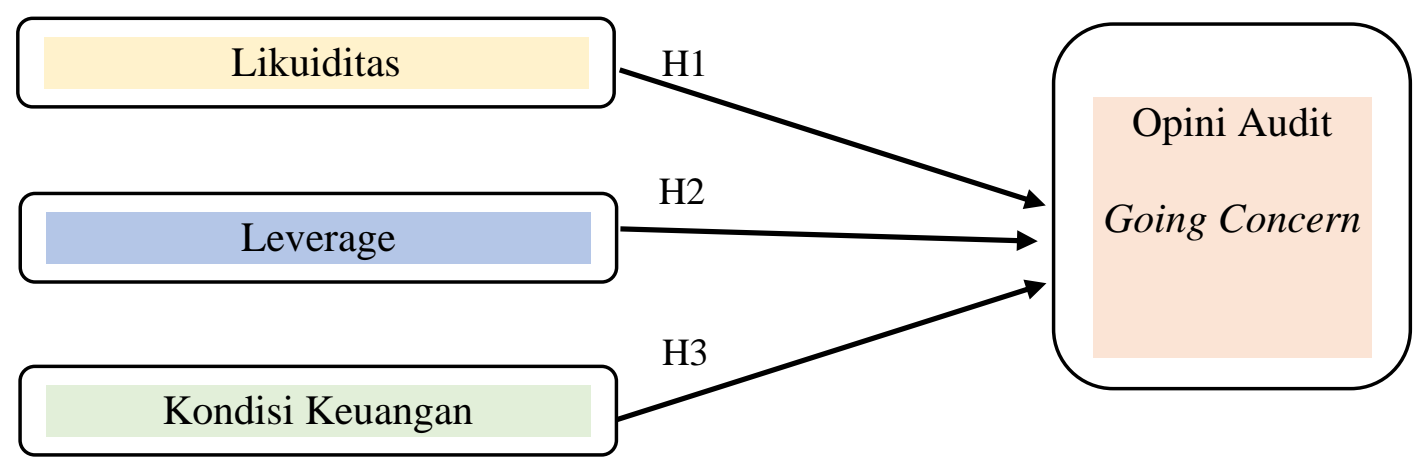

\section{Populasi dan Sample Penelitian}

Populasi yang digunakan dalam penelitian ini adalah perusahaan manufaktur yang terdaftar di Bursa Efek Indonesia (BEI) periode 2017-2019. Pemilihan sampel menggunakan metode purposive sampling sebagai metode pengambilan samplenya, dipilih berdasarkan kriteria-kriteria sebagai berikut:

1. Perusahaan manufaktur yang terdaftar di BEI periode $2017-2019$.

2. Perusahaan manufaktur yang menerbitkan informasi laporan keuangan secara lengkap dan telah diaudit oleh auditor independen selama periode penelitian (2017-2019).

3. Perusahaan manufaktur yang menerbitkan informasi laporan keuangan menggunakan mata uang rupiah selama periode penelitian (2017-2019).

4. Perusahaan manufaktur yang mengalami kerugian, setidaknya satu kali dalam periode penelitain.

\section{Variabel Dependent (Y)}

Variabel Dependent yang digunakan dalam penelitian ini adalah opini audit going concern

\section{Variabel Independent (X)}

Variabel Independent yang digunakan dalam penelitian ini adalah Likuiditas, Leverage dan Kondisi Keuangan. 


\section{Desain Penelitian}

Desain penelitian yang digunakan yaitu penelitian kausal merupakan penelitian untuk pengaruh-pengaruh antar satu atau lebih variable bebas (Independent variable) terhadap variable terkait (Dependent variable). Studi kasus ini menggunakan uji hipotesis untuk menjelaskan pemecahan masalah berdasarkan data sesuai dengan masalah yang diteliti pada perusahaan manufaktur yang terdaftar di Bursa Efek Indonesia (BEI).

\section{Metode Analisis Data}

Metode analisis data yang digunakan dalam penelitian ini adalah regresi logistik (logistic regression). Menurut (Ghozali, 2005:9)" Metode ini cocok digunakan untuk penelitian yang variabel dependentnya bersifat kategorikal (nominal atau non metrik

\section{Teknik Analisis Data}

\section{Menilai Kelayakan Model Regresi}

Menurut (ghozali 2016 : 218) analisis pengujian dengan logistic regression perlu menilai overall fit model terhadap data dengan memperhatikan output dari Hosmer and Lemeshow dengan hipotesis:

Ho = Model sesuai ( tidak ada perbedaan antara hasil obsevasi dengan hasil predeiksi)

Ha = Model tidak sesuai (ada perbedaan antara hasilobservasi dengan hasil prediksi)

Dasar pengambilan keputusan:

Jika probabilitas $>0,05$ maka $\mathrm{H} 0$ diterima

Jika probabilitas $<0,05$ maka $\mathrm{H} 0$ ditolak.

\section{Menilai Keseluruhan Model (Overal Model Fit)}

Perhatikan angka -2 Log Likelihood (LL) pada awal (block Number $=0$ ) dan angka -2 Log Likelihood pada block Number $=1$. Jika terjadi penurunan angka -2 Log Likelihood (block number $=0$ - block number $=1$ ) menunjukkan model regresi yang baik. Log Likelihood pada logistic regression mirip dengan pengertian "sum of squared error" pada model regresi sehingga penurunan Log Likelihood menunjukkan model regresi yang baik.

\section{Menguji Koefisien Regresi}

Beberapa hal yang perlu diperhatikan dalam uji koefisien regresi adalah:

1. Tingkat signifikan yang digunakan sebesar $5 \%$

Menurut Uyanto (2006: 27) menyatakan bahwa tidak terdapat suatu level signifikan yang dapat diaplikasikan untuk semua pengujian. Pada umumnya level $15 \%$ untuk riset konsumen, level $1 \%$ untuk quality insurance dan level $10 \%$ untuk political polling.

2. Kriteria penerimaan dan penolakan hipotesis:

Pada significant $\mathrm{p}$ - value (probabilitas value) jika p-value (significant) $>5 \%$ maka hipotesis alternative ditolak.

Jurnal Ilmiah Akuntansi dan Ekonomi Volume. 6 Nomor. 1, Februari 2021 Hal. 44 
Jika p-value (significant) $<5 \%$ maka hipotesis alternative diterima

Model analisis logistic regression yang digunakan adalah sebagai berikut:

$$
\mathrm{OAGC}=\alpha+\beta_{1} \mathrm{X}_{1}+\beta_{2} \mathrm{X}_{2}+\beta_{3} \mathrm{X}_{3}+\varepsilon
$$

Keterangan:

$$
\begin{array}{ll}
\text { OAGC } & \text { Opini Audit Going Conceren } \\
\mathbf{A} & =\text { Konstanta } \\
\boldsymbol{\beta 1}-\boldsymbol{\beta 3} & =\text { Koefisien regresi } \\
\mathbf{X}_{1} & =\text { Likuiditas } \\
\mathbf{X}_{\mathbf{2}} & =\text { Leverage } \\
\mathbf{X}_{\mathbf{3}} & =\text { Kondisi Keuangan } \\
\boldsymbol{\varepsilon} & =\text { Tingkat Kesalahan/ Error }
\end{array}
$$

\section{Hipotesis}

Hipotesis yang akan diuji adalah sebagai berikut

$\mathrm{H}_{1}$ : Likuiditas tidak berpengaruh terhadap opini audit going concern.

$\mathrm{HO}_{2}$ : Leverage tidak berpengaruh terhadap opini audit going concern.

$\mathrm{H}_{3}$ : Kondisi keuangan tidak berpengaruh terhadap opini audit going concern.

\section{ANALISIS HASIL DAN PEMBAHASAN}

\section{Uji Statistik Deskriptif}

Tabel 2

Descriptive Statistics

\begin{tabular}{|l|r|r|r|r|r|}
\hline & $\mathrm{N}$ & Minimum & Maximum & Mean & Std. Deviation \\
\hline X1 & 145 & .02 & 7.92 & 1.62 & 1.45 \\
X2 & 145 & -10.19 & 162.19 & 3.27 & 14.86 \\
X3 & 145 & -10.94 & 10.17 & 1.15 & 1.97 \\
Valid N (listwise) & 145 & & & & \\
\hline
\end{tabular}

Sumber: Data diolah, 2020

Hasil analisa deskriptif memperlihatkan bahwa jumlah sampel 145 Mempunyai 3 variabel yaitu Likuiditas (X1), Leverage (X2), Kondisi Keuangan (X3). Berdasarkan tabel 4.2 dengan jumlah pengamatan sebanyak 145 data dapat dijelaskan beberapa hal sebagai berikut:

Jurnal Ilmiah Akuntansi dan Ekonomi Volume. 6 Nomor. 1, Februari 2021 Hal. 45 
1. Likuiditas dalam penelitian ini diproksikan dengan Rasio Lancar (Current Ratio) menunjukkan nilai minimum sebesar 0,02 yaitu pada PT. Eterindo Wahanatama Tbk pada tahun 2018, sedangkan nilai maksimum sebesar 7,92 terdapat pada perusahaan PT. Multi Prima Sejahtera Tbk pada tahun 2018. Nilai mean sebesar 1,62 dan standar deviasi sebesar 1,45.

2. Leverage yang diproksikan dengan Debt to Equity Ratio (DER) menunjukkan nilai minimum sebesar -10,19 yaitu pada PT. Eterindo Wahanatama Tbk pada tahun 2017, sedangkan nilai maksimum sebesar 162,19 terdapat pada PT. Eterindo Wahanatama Tbk pada tahun 2017. Nilai mean sebesar 3,27 dan standar deviasi sebesar 14,86.

3. Kondisi Keuangan yang diproksikan dengan prediksi kebangkrutan Aldman dengan menggunakan z-score menunjukkan nilai minimum sebesar -10,94 yaitu pada PT. Tiga Pilar Sejahtera Food Tbk pada tahun 2017, sedangkan nilai maksimum sebesar 10,17 terdapat pada perusahaan PT. Inti Agri Resources Tbk pada tahun 2017. Nilai mean sebesar 1,15 dan standar deviasi sebesar 1,97.

\section{Matriks klasifikasi}

Tabel 3

Opini Audit Going Concern

Sumber: Data diolah, 2020

\begin{tabular}{|l|r|r|r|r|}
\hline & Frequency & Percent & Valid Percent & $\begin{array}{c}\text { Cumulative } \\
\text { Percent }\end{array}$ \\
\hline $\begin{array}{l}\text { Valid Non Opini Audit Going } \\
\text { Concern }\end{array}$ & 110 & 83.6 & 83.6 & 83.6 \\
Opini Audit Going Concern & 35 & 16.4 & 16.4 & 100.0 \\
Total & 145 & 100.0 & 100.0 & \\
\hline
\end{tabular}

Berdasarkan tabel 3 dapat dideskripsikan bahwa variabel dependen, yaitu opini audit going concern (OAGC), merupakan skala nominal yang menggunakan variabel dummy, dimana perusahaan yang menerima opini audit going concern diberi kode 1 (satu) sedangkan perusahaan yang menerima opini audit non going concern diberi kode 0 (nol). Variabel ini memiliki nilai data valid karena semua data diproses. Perusahaan yang menerima opini audit going concern sebanyak 21 sampel perusahaan atau 16,4\% dari total keseluruhan, sedangkan perusahaan yang tidak menerima opini audit non going concern sebanyak 107 sampel perusahaan atau 83,6\% dari total keseluruhan.

\section{Analisis Regresi Logistik}

Menilai Keseluruhan Model Fit (Overall Model Fit)

Jurnal Ilmiah Akuntansi dan Ekonomi Volume. 6 Nomor. 1, Februari 2021 Hal. 46 
Tabel 4

Hasil Pengujian Model Fit (-2 Log Likelihood awal)

Iteration History

\begin{tabular}{|c|c|c|}
\hline \multirow{2}{*}{ Iteration } & $-2 \log$ & Coefficients \\
\hline & likelihood & Constant \\
\hline Step $0 \quad 1$ & 115.778 & -1.344 \\
\hline
\end{tabular}

Sumber: Data diolah, 2020

Tabel 5

Hasil Pengujian Model Fit (-2 Log Likelihood akhir) Iteration History

\begin{tabular}{|c|c|c|c|c|c|c|}
\hline \multicolumn{2}{|c|}{ Iteration } & \multirow{2}{*}{$\begin{array}{l}-2 \text { Log } \\
\text { likelihood }\end{array}$} & \multicolumn{4}{|c|}{ Coefficient } \\
\hline & & & Constanta & $\mathbf{X 1}$ & $\mathbf{X} 2$ & $\mathbf{X 3}$ \\
\hline \multirow[t]{3}{*}{ ep 1} & 1 & 82.171 & -.825 & -.027 & .019 & -.123 \\
\hline & 2 & 73.230 & -.624 & -.130 & .025 & -.175 \\
\hline & 3 & 71.911 & -.344 & -.370 & .028 & -.185 \\
\hline
\end{tabular}

Sumber: Data diolah, 2020

Tabel diatas menunjukan nilai -2 Log Likelihood akhir adalah sebesar 71,911 Hal ini berarti nilai -2 Log Likelihood sebesar 115,778 mengalami penurunan pada nilai akhir yaitu dari nilai awal sebesar 115,778 menjadi 71,91 1 yang menunjukan bahwa model yang dihipotesiskan fit dengan data. Mempunyai arti bahwa H0 diterima dengan kata lain model fit dengan data dan dapat melanjutkan proses pengujian selanjutnya.

Koefisien Determinasi (Nagelkerke R Square)

Tabel 6

Uji Koefisien Determinasi

\begin{tabular}{|l|r|r|l|}
\hline \multicolumn{4}{|c|}{ Model Summary } \\
Step & $\begin{array}{c}\text {-2 Log } \\
\text { likelihood }\end{array}$ & $\begin{array}{c}\text { Cox \& Snell R } \\
\text { Square }\end{array}$ & $\begin{array}{c}\text { Nagelkerke R } \\
\text { Square }\end{array}$ \\
\hline 1 & $71.911^{\mathrm{a}}$ & .282 & .477 \\
\hline
\end{tabular}

Sumber: Data diolah, 2020

Jurnal Ilmiah Akuntansi dan Ekonomi Volume. 6 Nomor. 1, Februari 2021 Hal. 47 
Pada tabel 6 diatas menunjukkan nilai Nagelkerke $R$ Square yaitu sebesar 0.477 yang menunjukkan bahwa kemampuan variabel independen dalam menjelaskan variabel dependen sebesar 47,7\% dan selebihnya 52,3\% dijelaskan oleh variabel lain diluar penelitian ini

Menilai Kelayakan Model Regresi (Uji Hosmer and Lemeshow's Goodness of Fit Test)

Tabel 7

Hasil Uji kelayakan Model Regresi Hosmer and Lemeshow test

\begin{tabular}{|l|r|r|r|}
\hline Step & Chi-square & df & \multicolumn{2}{|c|}{ Sig. } \\
\hline 1 & 13.164 & & 8 \\
\hline
\end{tabular}

Hasil pengujian statistic menunjukkan chi- square 13,164 dengan nilai siginfikansi 0,106 > 0,05, maka Ho diterima. Hal ini berarti tidak ada perbedaan antara model dengan data sehingga model mampu memprediksi nilai observasinya atau dapat dikatakan model dapat diterima karena cocok dengan data observasinya.

Artinya tidak ada perbedaan antara likuiditas,leverage dan kondisi keuangan terhadap opini audit going concern sehingga model mampu memprediksi nilai observasinya atau dapat dikatakan model dapat diterima karena cocok dengan data observasinya

\section{Pengujian Koefisien Regresi (Pengujian Hipotesis)}

\section{Signifikansi Model Secara Simultan (Uji Omnibus)}

Tabel 9

\section{Omnibus Test}

\begin{tabular}{|rl|r|r|r|}
\hline & & Chi-square & Df & \multicolumn{1}{c|}{ Sig. } \\
\hline Step 1 & Step & 42.353 & 7 & .000 \\
& Block & 42.353 & 7 & .000 \\
& Model & 42.353 & 7 & .000 \\
\hline
\end{tabular}

Sumber: Data diolah, 2020

Dapat dilihat pada tabel 4.11 hasil omnibus test menunjukkan bahwa nilai $p$-value sebesar $0,000<0,05$. Nilai $p$-value labih besar dari tingkat signifikansi sebesar 0,05 maka $\mathrm{H}_{0}$ diterima yang berarti bahwa variabel independen berpengaruh secara simultan terhadap dependen (Opini Audit Going Concern).

Jurnal Ilmiah Akuntansi dan Ekonomi Volume. 6 Nomor. 1, Februari 2021 Hal. 48 


\title{
Uji Signifikansi Model Secara Partial
}

\author{
Analisis Regresi Logistik
}

Tabel 10

Koefisien Regresi Model

\begin{tabular}{|c|c|c|c|c|c|c|c|c|c|}
\hline & \multirow[b]{2}{*}{ B } & \multirow[b]{2}{*}{ S.E. } & \multirow[b]{2}{*}{ Wald } & \multirow[b]{2}{*}{ Df } & \multirow[b]{2}{*}{ Sig. } & \multirow[b]{2}{*}{$\operatorname{Exp}(B)$} & \multicolumn{2}{|c|}{ 95\% C.I.for EXP(B) } \\
\hline & & & & & & & & Lower & Upper \\
\hline \multirow[t]{4}{*}{ Step $1^{a}$} & $\mathrm{X} 1$ & -.360 & .457 & 618 & 1 & 418 & .681 & .677 & 1.715 \\
\hline & $x 2$ & .018 & .014 & 1.183 & 1 & .047 & 1.018 & .780 & 1.068 \\
\hline & X3 & -.175 & .123 & 1.821 & 1 & 156 & .821 & .630 & 1.070 \\
\hline & Constant & -.334 & 2.834 & .004 & 1 & .907 & .709 & & \\
\hline
\end{tabular}

Sumber: Data diolah, 2020

Menunjukkan hasil uji regresi logistic pada tingkat signifikansi ( $\alpha$ ) 5\%. Dari hasil pengujian regresi logistic tersebut, maka persamaan regresinya adalah sebagai berikut:

$$
\begin{aligned}
\text { OAGC }= & -0,334-0,360 \text { (Likuiditas) }+0,018 \text { (Leverage) }-0,175 \text { (Kondisi } \\
& \text { Keuangan) }+\varepsilon
\end{aligned}
$$

1. Nilai konstanta pada persamaan regresi di atas sebesar $-0,334$ artinya apabila variable likuiditas, leverage, kondisi keuangan bernilai 0 (nol) maka nilai opini audit going concern akan memiliki nilai sebesar $-0,334$.

2. Hasil pengujian menunjukkan bahwa variabel likuiditas yang diproksikan dengan current ratio memiliki koefisien regresi sebesar $-0,360$. artinya jika variable independen lain nilainya tetap dan variable X1( likuiditas) mengalami kenaikan $1 \%$ maka variable $\mathrm{Y}$ (opini going concern) akan menurun sebesar 0,360 .

3. Hasil pengujian menunjukkan bahwa variabel leverage yang diproksikan dengan debt equity ratio memiliki koefisien regresi sebesar 0.018 . Artinya jika variable independen lain nilainya tetap dan variable X2(leverage) mengalami kenaikan $1 \%$ maka variable $\mathrm{Y}$ (opini going concern) akan meningkat sebesar 0,018 .

4. Hasil pengujian menunjukkan bahwa variabel kondisi keuangan yang diproksikan dengan $z$-score memiliki koefisien regresi sebesar -0,175. Artinya jika variable independen lain nilainya tetap dan variable X3(kondisi keuangan) mengalami kenaikan $1 \%$ maka variable $\mathrm{Y}$ (opini going concern) akan menurun sebesar 0,175 . 


\section{Pembahasan dan Interpretasi Penelitian}

\section{Pengaruh Likuiditas Terhadap Pemberian Opini Audit Going Concern}

Variabel likuiditas memiliki koefisien regresi sebesar -0,360 dengan tingkat signifikan 0,418 yang lebih besar dari tingkat signifikansi $(\alpha) 0,05(0,428>0,05)$. Dapat disimpulkan bahwa $\mathrm{H}_{1}$ yang menyatakan likuiditas tidak berpengaruh terhadap pemberian opini audit going concern diterima.

\section{Pengaruh Leverage Terhadap Pemberian Opini Audit Going Concern}

Hasil pengujian menunjukkan bahwa variabel leverage yang diproksikan dengan Debt to Equity Ratio (DER) memiliki koefisien regresi sebesar 0,018 dengan tingkat signifikan 0,047 lebih kecil dari tingkat signifikansi $(\alpha) 0,05(0,047<0,05)$. Dapat disimpulkan bahwa $\mathrm{HO}_{2}$ yang menyatakan leverage tidak berpengaruh terhadap pemberian opini audit going concern ditolak. Hal ini mengindikasikan bahwa besar kecilnya rasio leverage menjadi pertimbangan auditor dalam memberikan opini audit going concern.

\section{Pengaruh Kondisi Keuangan Terhadap Pemberian Opini Audit Going Concern}

Hasil pengujian menunjukkan bahwa variabel kondisi keuangan yang diproksikan dengan Z-score Altman memiliki koefisien regresi negatif sebesar -0,175 dengan tingkat signifikan 0,156 yang lebih besar dari tingkat signifikansi $(\alpha) 0,05$ $(0,156>0,05)$. Dapat disimpulkan bahwa $\mathrm{H}_{3}$ yang menyatakan rasio kondisi keuangan tidak berpengaruh terhadap pemberian opini audit going concern diterima.

Kondisi keuangan yang diukur dengan model prediksi Altman dapat digunakan untuk menilai baik buruknya keuangan perusahaan. Selain itu auditor dapat mengeluarkan opini audit going concern jika keuangan perusahaan mengalamai kondisi buruk. Namun hasil penilitian ini mendapatkan hasil bahwa kondisi keuangan tidak berpengaruhi terhadap audit going concern hal ini disebabkan data penelitian menunjukkan sampel hanya 47,6 \% dari seluruh total sample perusahaan yang memperoleh opini audit going concern. Hal ini dapat memberikan petunjuk bahwa perusahaan manufaktur selama periode penilitian dalam kondisi baik.

\section{Kesimpulan}

\section{KESIMPULAN DAN SARAN}

Berdasarkan rumusan masalah, tujuan penelitian, landasan teori, hipotesis dan hasil pengujian yang dilakukan, maka dapat disimpulkan sebagai berikut:

1. Likuiditas tidak berpengaruh terhadap pemberian opini audit going concern.

2. Leverage berpengaruh terhadap pemberian opini audit going concern.

3. Kondisi keuangan yang diukur dengan menggunakan model prediksi z-score Altman tidak berpengaruh terhadap pemberian opini audit going concern.

Jurnal Ilmiah Akuntansi dan Ekonomi Volume. 6 Nomor. 1, Februari 2021 Hal. 50 


\section{Saran}

Saran-saran yang dapat disampaikan bedasarkan penelitian ini adalah sebagai berikut:

1. Koefisien determinasi (Nagelkerke $\mathrm{R}$ square) adalah sebesar 0.477 yang menunjukkan bahwa kemampuan variabel independen dalam menjelaskan variabel dependen sebesar $47,7 \%$ dan selebihnya $52,3 \%$ persen dijelaskan oleh variable- variabel lain di luar model penelitian. Hal ini berarti masih ada variabel lain yang perlu diidentifikasi untuk menjelaskan pemberian opini audit going concern. Penelitian selanjutnya dapat memilih proksi lain yang bisa mengukur variabel-variabel tersebut agar lebih tepat sehingga dapat membuktikan pengaruh terhadap pemberian opini audit going concern.

Variabel lain yang secara teoritis mungkin dapat memengaruhi pemberian opini audit going concern, misalnya audit delay, mekanisme corporate governance, auditor switching, rasio arus kas dan kondisi keuangan yang dapat diprediksi dengan pengukuran Altman Model, Springate Model dan Revised Altman Model.

2. Penelitian ini hanya dilakukan pada perusahaan manufaktur yang terdaftar di Bursa Efek Indonesia, penelitian berikutnya dapat melakukan penelitian dengan objek yang berbeda misalnya perusahaan sektor perbankan dan perusahan sektor real estate.

\section{DAFTAR PUSTAKA}

Adityaningrum, Endah. 2012. "Analisis Hubungan Antara Kondisi Keuangan Perusahaan dengan Penerimaan Opini Audit Going Concern”. Skirpsi Publikasi. Semarang: UNDIP.

Agoes, Sukrisno. 2012. "Auditing: Petunjuk Praktis Pemeriksaan Akuntan oleh Akuntan Publik". Jilid 1, Edisi 4, Jakarta: Salemba empat.

Agus Sartono. 2012. Manajemen Keuangan Teori dan Aplikasi. Edisi 4. BPFE. Yogyakarta.

Alichia, Yashinta Putri. 2013. "Pengaruh Ukuran Perusahaan, Pertumbuhan Perusahaan, dan Opini Audit Tahun Sebelumnya Terhadap Opini Audit Going Concern". Jurnal Akuntansi, Universitas Negeri Padang, Vol. 1, No. 1.

Alichia, Yashinta Putri.2013. "Pengaruh Ukuran Perusahaan, Pertumbuhan Perusahaan, dan Opini Audit Tahun Sebelumnya Terhadap Opini Audit Going Concern". Universitas Negeri Padang.

Altman, Edward I. 1968. "Financial Ratios, Discriminant Analysis and the Prediction of Corporate Bankruptcy”. Jurnal Keuangan, Vol.23,No.4.

Jurnal Ilmiah Akuntansi dan Ekonomi Volume. 6 Nomor. 1, Februari 2021 Hal. 51 
API. 2011. Standar Profesi Akuntan Publik. Salemba Empat, Jakarta. 2011. Standar Profesional Akuntan Publik, Salemba Empat, Jakarta Lenard, Mary Jane, Pervaiz Alam, and David Booth. "An Analysis of Fuzzy Clustering and Hybrid Model for Auditor's Going Concern Assesment. "Journal Decision Sciences (DSI) ISSN:001-7315, Vol.31, Iss.4, Fal 12000, p.861.

Ardi Murdoko Sudarmadji dan Lana Sularto. 2007. Pengaruh Ukuran Perusahaan, Profitabilitas, leverage, dan Tipe Kepemilikan Perusahaan Terhadap Luas Voluntary Disclosure Laporan Keuangan Tahunan, Proceeding PESAT, Volume 2.

Arens et al., 2006, Auditing and Integrated Approach, 11th, New Jersey: Prentice Hall.

Chen, K. C. W., and B. K. Church.1992. "Default on Debt Obligation and the Issuance of Going-Concern Report". Auditing: A Journal of Practice \& Theory, Fall. 30 49.

Dewayanto, Totok. 2011. Analisis Faktor-Faktor Yang Mempengaruhi Penerimaan Opini Audit Going Concern Pada Perusahaan Manufaktur Yang Terdaftar Di Bursa Efek Indonesia. Vol. 6 No. 1 Juni 2011 : 81 - 104.

Fahmi, Irham. 2012. Analisis Laporan Keuangan. Cetakan ke-2. Bandung: Alfabeta.

Fanny, Margaretta dan Saputra, S. (2005). "Opini Audit Going Concern: Kajian Berdasarkan Model Prediksi Kebangkrutan, Pertumbuhan Perusahaan, Dan Reputasi Kantor Akuntan Publik (Studi Pada Emiten Bursa Efek Jakarta)”. Simposium Nasional Akuntansi VIII. 966-978. 